\title{
Patterns of Civil-Military Relations: Patronage \& Clientelism
}

\author{
Andreas Heinemann-Grüder*
}

\begin{abstract}
The article argues that the security forces represent a fundamental building block of fragile authoritarian regimes, they exploit the lack and fill the void of core functions of weak states rather than just representing a "state within a state". In the absence of functioning institutional delineations of competencies and of checks and balances, the security forces assume tasks, functions and roles far beyond their organizational mandate. The security sector contributes to sustaining state fragility, leading to a fundamental crisis of statehood. The article presents findings of a project on the stabilizing and de-stabilizing roles of security forces in Central Asia.
\end{abstract}

Keywords: Security forces, Central Asia, state fragility

Sicherheitskräfte, Zentralasien, staatliche Fragilität

\section{Hierarchy or Fragmentation?}

$\mathrm{M}$ ost studies on post-Soviet regimes are puzzled by the continuity of non-democratic governance despite the substantial time passed since the collapse of the Soviet Union, and despite poor regime performance, the imperatives of democratization, and a widespread sense of delegitimization of these regimes. Most interpretations refer to the persistence of historical legacies and behavioural patterns unfavourable for democracy or to the lack of prerequisites for democracy, such as national identity hegemony, an elite consensus or a favourable external environment (Collins 2009). Most accounts thus rely on "deep" historical or macrostructural explanations.

This article, in contrast, suggests that some of the answer is to be found instead in the operating mode of security services of fragile authoritarian states. The operating mode of the security services is perplexing. On the one hand the security services represent a unitary, highly centralized, vertically integrated structure, where functional divisions are distributed among security ministries and state agencies, and where major operating and strategic decisions are formulated and controlled by the chief executive (the president) and transmitted to subordinates, corresponding thus to a vertical and unitary model of hierarchy. On the other hand, security forces perform a wide range of roles with a high degree of autonomy, while competing against one another, particularly in extracting and controlling resources, thus rather resembling a model of fragmentation. How do unitary authoritarian hierarchy and fragmentation in the operation of security forces fit together? The answer rests, I argue, on the interplay between overarching regime features and the operating mode of the security forces.

I demonstrate this contention by looking at three post-Soviet Central Asian states. I show that the control patterns derive from well-established patronage systems that were latent in Soviet states and have since then resurfaced as a core operating mode. Data derive from field study in Tajikistan, Kyrgyzstan,

* Andreas Heinemann-Grüder, Dr. PD, heads the Academy for Conflict Transformation, Bonn and Uzbekistan, where some 30 interviews were conducted with government and academic figures on the issue of civilmilitary relations.

\section{Institutional Features and Control Patterns}

In institutional terms, three overarching features of the regulation of the security sector stand out in Central Asia: the concentration of decision-making power in the presidency, the absence of a clear demarcation of internal and external security, and an almost exclusive agenda-setting by the security establishment itself. The formal structures of most internal security forces have changed little since the end of the Soviet Union. In formal terms, the civilian President is the supreme commander, who is constrained by few institutional checks and balances. The formal and de facto competencies of security organs and their oversight bodies vary among the Central Asian states, yet control and oversight by parliaments, the media, and independent research is ineffective or non-existent. The common predominance of heads of security services with a background in the "power ministries" (Ministries of National Security, Interior, Defense, Emergency Situations, State Procurator, Border Guard, Presidential Guard, Customs Service, etc.) has implications for civil-military relations. Being at the top of the decision-making chain, the "power ministries" weigh in on national policy matters, both domestic and external. Policy formulation is substantially determined by threat perceptions, organizational demands, the informational bias and corporate identities of the security services. They exercise privileged access to the president, crowd out the civilian point of view, and pressure the president in directions that serve the security institutions themselves.

The standard control pattern for an authoritarian president is to concentrate all major power in his own hands and to divide all the subordinate powers between different security agencies. This limits the ability of the security forces to coalesce, to form corporate identities and to provide policy guidance in unison. The Soviet model of centralist-hierarchical control is supplemented by a high degree of de facto fragmentation and rent-seeking coalitions. Each division of the security forces 
advances its own preferences regarding the overall strategic decisions and competes with other divisions concerning resource allocation and access to the president. Each service is motivated to cut a better deal for itself in terms of access to presidential decision-making, and to blame competing services for inefficiency and corruption. A reshuffling of leading personnel, and symbolic "purification" measures - often with public exposure of those punished - is a common practice.

The president at the core allows, and at times even encourages, interdivisional conflict by playing his subordinates and counsellors against one another, thus becoming embroiled in an organizational disarray that cripples the ability to govern effectively (Cooley 2005). The more governmental (that is, presidential) power is centralized and unchecked by the parliament and the judiciary, the greater is governmental control over the economy. The less the security services are sufficiently financed, and the deeper the security services become entrenched in personalized rule and patron-client relations, the greater is their need for extra-budgetary economic resources inherent in such relations.

Furthermore, authoritarian presidents of the mould discussed are more likely to ensure that close kin and clan members, who, in the Central Asian context are more to be trusted, enjoy disproportionate access to subordinate delegated powers, thus causing a contraction of the social basis from which leadership can emerge. A contraction of the social basis of the regime (ethnic, regional and politico-administrative) has a double effect - it increases the necessity to forcibly suppress the dissent of those excluded and thus increases the likelihood that authoritarian rulers perceive dissent as a threat to regime stability as a whole, and it justifies an expansion of security force intervention in political processes. A contraction of the social regime base does not just alienate those excluded elites and social groups, it undermines the loyalty of the security forces to the patron as well.

To illustrate these points, I now turn to examples from three Central Asian states.

\section{Tajikistan, Kyrgyzstan, and Uzbekistan Compared}

All the Central Asian presidents in this sample show signs that they feel insecure about the stability of their regimes, admittedly to various degrees. In order to reduce this insecurity, the presidents of Tajikistan, Kyrgyzstan, and Uzbekistan rely heavily in their selection of leading personnel for the security forces on family members, cronies or fellow natives from their home regions, installing what are in effect quasi-sultanistic regimes.

As a result of the power-sharing peace agreement, which ended the civil war (1992-97), President Rahmon of Tajikistan rewarded those who had supported the government during the civil war with leading positions in the "power ministries" (Kayani 2006). During the 1990s an almost complete removal of Soviet - mostly ethnic Russian - cadres took place in the Tajikistan security sector, particularly in the secret service and the Ministry of Interior. Personal loyalty to the president as well as ethnic and regional allegiances often took precedence over professional merits. As a result of the peace agreement Rahmon had to incorporate commanders and ex-combatants of the Islamist and ethno-regional insurgents into the government, particularly the security forces. This caused a constant risk of disloyalty as well as criminalization of the security forces, since the insurgent leaders had no or little previous administrative or security experience, and some had been involved, as insurgent leaders, in purely criminal activities. The appointments also annoyed those regions and groups which were excluded from the peace agreement. However, from 2000 onwards, Rahmon marginalized or expelled former insurgents, a few at a time, from the security services and put fellow natives from his home region, Kulyab, into leading positions, causing additional resentment among the under-represented and newlyexcluded regions and ethnic groups (Seifert 2010). While the professionalism of the security services substantially improved as a result, the social basis of Rahmon's regime contracted, stimulating some local field commanders to mount violent resistance against the government (Mullodzhanov 2009).

Former Kyrgyzistan president Bakiyev (2005-2010) put trusted suppressors of opposition groups at the helms of security agencies and the Ministry of Interior, which were the decisive pillars of Bakiyev's hold on power. As the social basis of Bakiyev's regime contracted and his reliance on the oppressive politics of the Ministry of Interior grew, public resentment swelled and opposition radicalised. Corruption, cronyism, arbitrariness and protection of the personal enrichment of the president's family by the security services became the targets of widespread discontent - similar to the ouster of Bakiyev's predecessor, president Akayev, in 2005.

On April 7, 2010, protesters seized the internal security headquarters and a state TV channel after fatal clashes with government forces in different parts of Kyrgyzstan. Although not a unified actor, the opposition forces had agreed not just on a new prime minister, but on a new interior minister and new chief of the secret service. During the riots, which ended with Bakiyev's ouster, opposition leader Keneshbek Duishebayev took over the office of the Chief of the National Security Agency (secret service); protesters also stormed the Ministry of Interior and the office of the General State Procurator.

Up to 2005 Uzbekistan's President Karimov primarily relied on the Ministry of Interior, too. After the Andijan massacre (2005) Karimov re-organized the security sector: he “... took the opportunity to reduce inter-service rivalry and ensure closer ties between the regime and the security forces by increasing the security sector's individual and corporate benefits." (Forster 2007: 63) If one looks at the post-Andijan re-organization in Uzbekistan from a comparative perspective, one discerns a similar pattern to Kyrgyzstan and Tajikistan in recent years: the appointment of people from the president's kinship network or region of origin, combined with a divide-and-rule strategy. The pattern of divide and rule, rivalry, and competition tends to make the presidents highly dependent on service parochialism. The approach allows for a relatively broad representation of diverse regional, bureaucratic and ethnic interest groups; however, the costs for preventing potential defection are high. 
Signs of defection or unforeseen shocks (like the Andijan massacre) may thus lead to a shrinking of the regime base, e.g., the primacy of one segment of the security sector or a selection pattern, which only promotes the region or ethnic group deemed most loyal to the president (Southeners in Kyrgyzstan or Kulyabis in Tajikistan).

\section{Patron-Client Relations and Non-Mandated Functions}

Patron-client networks are in a broad sense a form of corruption, when understood as the decomposition or disintegration of governmental services, as perversion of institutions and as moral deterioration (Heidenheimer and Johnston 2002: 7). "Corruption" stresses the non-application of formal rules and socially accepted standards, while the notion of patronclient networks describes the underlying mechanism and its logics, e.g., repeated, personalized, highly selective, privileged transactions between a state agent and inferior clients. The patron is superior due to his power to enforce or not to enforce laws, to regulate markets, to distribute subsidies, and to allocate public resources.

Patron-client relations seem to be endemic in countries transiting from one economic or political regime to another, offering thus ample opportunities for allocating resources, property rights and enforcing norms and laws in a particularistic way. Old institutions decay, while new ones do not enjoy legitimacy. The less the transition process - e.g., the disintegration of past social exchange and welfare mechanisms and the emergence of capitalism and new economic classes - is legally regulated in an open, accessible, transparent, and democratic polity, the more it seems unjust, unfair, anarchic and illegitimate (Khan 2002: 468). Against this backdrop, patron-client relations become a means to re-distribute the spoils and costs of transformation: the inherent unfairness of privileging the "nouveau riches" is smoothed by attempts of the patron to purchase support or legitimacy from disenchanted or disillusioned state agents, opposition groups, or other potential trouble makers.

Corrupt security services are part and parcel of deeply entrenched patron-client exchanges and, they are often at the core of these exchanges. The autonomy of distinct security services results from their oversight over business, foreign or domestic trade sectors or trans-border shipments. Security services - particularly the Ministry of Interior, the customs service, the border guard and the secret service - thus become economic intermediaries and "market regulators". They are essential for sustaining patronage, clientelism and nepotism. Control over scarce resources and a continuation of privileged access by ruling elites is not only exercised because "old elites" were able to maintain or expand their power base after independence, but due to the management and governance of personalistic politics and patronage networks through domestic security services.

The exertion of influence by the security forces is less visible, but in a way more substantial than under a direct military rule: security services form the system rather than merely the government. The Secret Service and the Ministry of Interior represent the core of the governments, they are the ones who keep the authoritarian presidents in power - or refrain from doing so if the patron becomes too sultanistic, e.g., exclusively oriented towards the spoils for his family and cronies. The security forces represent the backbone of the government by filling the void of parties and parliaments. They function as party substitutes by selecting political elites, by mediating between corporate interests, and by representing different regional and ethnic clans in the executive. Security forces function as substitutes for open media and independent research by being almost the only ones providing information to the presidents, and they also operate as arbiters between different clan and business interests.

The security apparatuses represent heterogeneous agencies, they compete over resources, representation and regime access and are heavily involved in the shadow economy. Parts of the security sector in Central Asian states suffer from underfunding, personnel selection on the basis of personal loyalty or bribery, and a rampant policy of favours. The police break the law simply to cover running costs, devoting much of their time to illegally boosting their small official salaries. The police have become closely entangled in criminal networks engaged in prostitution rings, contraband and drug trafficking (ICG 2002). Security services are responsible for gross human rights abuses, which have in turn fuelled extremist or criminal opposition to the regime.

The police, the secret service, the state procurator, the border guards, customs, and special agencies (such as anti-corruption agencies) are perceived by the public as arbitrary, selfish and extractive institutions. The problem rests in part on the lack of professionalism, but also on resource limitations, which stimulate extractive behaviour and misdirection of funds. The "role model" provided by the president and his immediate environment trickles down to law enforcement at large. The security services are thus a cause of instability on several fronts: they contribute to the de-legitimization of the state, the marginalization of non-violent civil society, the radicalization of dissent (with a securitization of domestic politics in turn), the bad investment climate, and the postponement of economic reforms.

The military, although subject to patron-client relationships too, is probably the least autonomous security organization due to the relative lack of distributional power, its lack of leverage on law enforcement, and the relative functionality of its unitary control structure. The military is, however, highly unpopular in the Central Asian countries; many young men try to avoid conscription, and service dodging is rampant (Karabayev 2010). By comparison, young men pay tremendous sums in order to get entrance into the police, the customs service, border guards or the secret service - the investment by the whole family or clan usually pays off quite soon (Taksanov 2008).

In order to keep the security services loyal, the autocratic head of government allows some measure of corruption, nepotism, and engagement in the shadow economy: the sultanism of the president and his cronies is less vulnerable to one potential source of criticism once the law enforcement agencies are 
involved in the same practices. Given budgetary constraints, discontent in the security services is smoothed if there are ample opportunities to secure material gains by illegal means. Finally, involvement in the shadow economy allows each service to collect compromising material on its competitors, thus increasing the potential for scoring points with the president when he decides to act to punish excesses.

While the involvement of the security services in the shadow economy increases the presidential leverage over the security services, it decreases the steering capacity of the executive. The security services embody thus the paradoxical co-existence of strong and fragile state features - they are strong on control over distribution networks, extracting and diverting public resources as well as on repression, but weak on formulating coherent goals, implementing policies, and on legitimacy. Against the backdrop of the Central Asian experience one could argue that a highly exclusive, sultanistic rule diminishes the commodities a patron can offer to his clients, thereby critically undermining loyalty. It may lead to such a degree of fragmentation, de-institutionalization, de-professionalization and structural sclerosis that the control of and by the security forces turns into a pure exchange of goods and favours. Security forces then act on the basis of a situational cost-benefit calculus; a central executive unable to deliver public goods may no longer enjoy loyalty or control at all. Sultanism thus results in the erosion of repression and sanctioning capacities by the patron. The outright disengagement of the Kyrgyz security forces during the ousting of the Kyrgyzstan government in April 2010 illustrates the point. The social basis, e.g., inclusiveness, of the authoritarian and repressive Uzbek president Karimov is by comparison broader: in contrast to his Kyrgyz colleague, the Uzbek patron still has access to public goods with which to ensure the loyalty of his clients.

\section{External Security Sector Reform Incentives}

It comes as no surprise that security sector reform (SSR), as promoted by NATO or the OSCE, is often portrayed as an attempt to sponsor revolution or to impose alien Western values. The focus of international assistance is on police forces and border guards in Central Asia. It involves training, studies abroad and technical assistance, but little attention is paid to legal and democratic principles of control over the security services. External assistance by the OSCE, the UN's Office for Drug Control and Crime Prevention, NATO, and individual NATO members is often project-based, rarely coordinated and not driven by long-term agendas of behavioural change. The OSCE's mandate depends on approval by the Central Asian countries. Due to their economic dependency on external aid, Kyrgyzstan and Tajikistan are more open to exchanges on the OSCE's Code of Conduct on Politico-Military Aspects of Security than Uzbekistan. However, most assistance is technical and determined by the wish lists of the local Ministries of Interior or the border guards as well as donor's priorities, it is rarely linked to a reform of institutional cultures. Therefore, the security services have "little incentive to change if that means undermining their personal political and financial power bases" (ICG 2002).

\section{Conclusions}

Corrupt and arbitrary security services are key indicators of the legitimacy crisis of the Central Asian regimes. Repressive, extractive, and kleptocratic regimes with decreasing resources and increasing income inequality contribute to the legitimization crisis of the Central Asian regimes and are prone to feed "fundamentalist" movements. Fragile state governance includes the lack of institutional control over security forces, which represent a principal source of domestic insecurity themselves. Security forces thus contribute to the de-legitimization of the state.

The influence of the security forces on domestic politics results from imprecise assignments of authority, the dependency of the president on information flows controlled by security services, protection and resource extraction controlled by security agencies, and the lack of political or ideological integration throughout the government. The presidents therefore face principal-agent problems. The presidents try to minimize the impact of agency autonomy through frequent personnel rotation, collection of compromising material, screening and selection procedures, by establishing overlapping authorities, by ad hoc inspections, and by rewarding the most compliant agents.

With governance performance in decline the competencies of security forces are likely to expand. A perception of presidential weakness may cause unpredictable events. Lack of institutionalized access channels is likely to transform even mild opposition to the regime into dissent and rebellion expressed through religious and ethnic agendas. The regime then uses repressive measures, legitimized as anti-fundamentalist actions, as an important tool for regime stabilization. It would appear that there is a self-enforcing dynamic between declining regime capacity, increased repression and the rise of opposition movements with a fundamentalist or violent agenda.

Given the deep entrenchment of the domestic security services in the political regime and their political economy, the perceived intensity of threats to regime survival, and the weakness or absence of institutionalized checks and balances, it is unlikely that the influence of domestic security services on decisionmaking will diminish in the near future. An institutional reform of the security sector is unlikely to be advanced when the whole governmental system is characterized by an unconstrained concentration of powers in the presidency, patron-clientrelationships, and inherent corruption.

Reform initiatives should arguably start with strengthening the legal constraints on security services by delineating their competences, by fostering the political and economic independence of the judiciary and by promoting oversight and investigation agencies with a mixed background. A mix of economic and political incentives could launch an evolutionary reform process. 


\section{References}

Collins, Kathleen: Clan Politics and Regime Transition in Central Asia, Cambridge University Press 2009.

Cooley, Alexander: Logics of Hierarchy. The Organization of Empires, States, and Military Occupations, Ithaca, London: Cornell University Press 2005.

Forster, Peter K.: International Factors Stopping Security Sector Reform: The Uzbek Case. China and Eurasia Forum Quarterly, vol. 5, No. 1 (2007), pp. 61-66.

Heidenheimer, Arnold J.; Michael Johnston (eds.), Political Corruption. Concepts \& Contexts, New Brunswick: Transaction Publishers 2001.

International Crisis Group: Central Asia: The Politics of Police Reform. Asia Report No. 42.10 December 2002.

Karabayev, Aibek: Kyrgyz Military Analysts Suggest Unorthodox Ways to Attain Regional Security, http://centralasiaonline.com/cocoon/caii/xhtml/en_GB/features/caii/features/ main/2010/03/23/feature-01.

Kayani, Saima Ashraf: Islam and Nationalism in Tajikistan, Islamabad: Quaid-e-Azam University, 2006.

Khan, Mushtaq H.: Patron-Client Networks and the Economic Effectgs of Corruption in Asia, in: Arnold J. Heidenheimer, Michael Johnston (eds.), Political Corruption. Concepts \& Contexts, New Brunswick: Transaction Publishers 2001, 467-488.

Mullodzhanov, Parviz: Silovye struktury v Tajikistane. Voprosy prevyshenia polnomochii i kontrolya. Unpublished paper, Dushanbe 2009.

Seifert, Arne: Friedensschluss und Systemtransformation:Was lehrt der Rückblick auf den tadschikischen Bürgerkrieg? In: Friedensgutachten 2010, ed. by C. Fröhlich, M. Johannsen, B. Schoch, A. Heinemann-Grüder, J. Hippler, Münster: Lit Verlag 2010.

Taksanov, Alisher: Korruptsiya v pravoochranitel'nykh organakh Uzbekistana. Paper presented at the Conference "Security Challenges and Security Apparatuses in Central Asia", OSCE Academy Bishkek, 15 July 2008.

\section{Ein Kontinent im Wandel.}

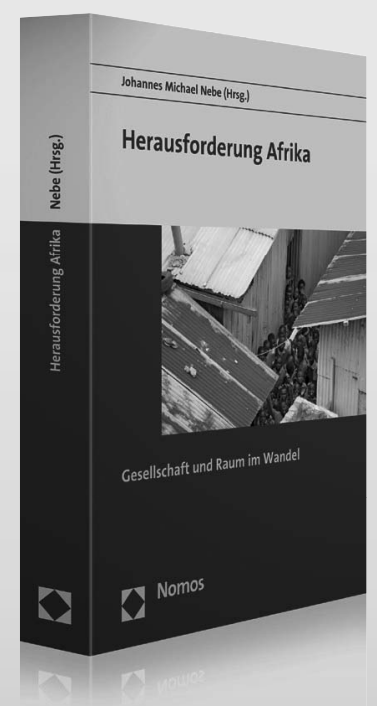

\section{Herausforderung Afrika}

Gesellschaft und Raum im Wandel

Herausgegeben von Dr. Johannes Michael Nebe

2011, 432 S., brosch., 49,-€

ISBN 978-3-8329-6314-9

In 26 Beiträgen wird von europäischen und afrikanischen Autoren und Autorinnen ein differenziertes vielleicht auch überraschend neues Bild von Afrika gezeichnet. Unter anderem werden die Themen Entwicklungspolitik, Gesundheit und Sicherheit, wirtschaftliche Entwicklung, Migration und Bevölkerung, Umwelt und Verkehr sowie Bildung von Wissenschaftlern und Praktikern aufgegriffen. 